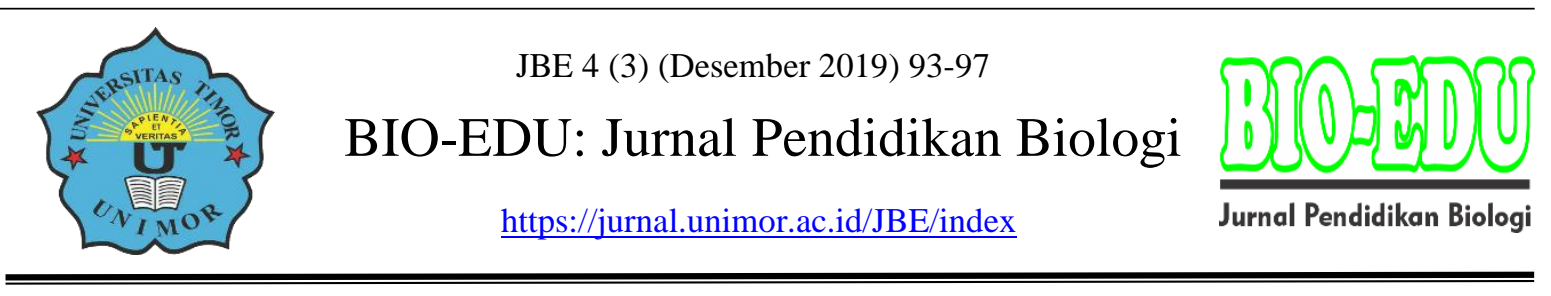

\title{
Uji Efektivitas Sediaan Sirup Antipiretik Ekstrak Flavonoid Daun Alvokad (Persea Americana Mill) pada Tikus Putih (Rattus Novergicus L) yang Diinduksi Vaksin DPT-HB
}

\author{
Natalia Latjandu ${ }^{1}$, Diyan Oroh ${ }^{2}$ \\ ${ }^{1,2}$ Program Studi Farmasi, Universitas Trinita \\ Email: nlatjandu@gmail.com
}

DOI: https://doi.org/10.32938/jbe.v4i3.423

\begin{abstract}
Abstrak
Penelitian ini bertujuan untuk mengetahui dosis yang paling efektif dalam menurunkan demam pada tikus putih yang diinduksi vaksin DPT-HB. Metode penelitian bersifat eksperimental laboratorium dengan menggunakan metode tanpa pemanasan untuk pembuatan sirup. Hasil pengukuran suhu awal pada semua kelompok perlakuan tikus putih yang merupakan suhu normal dari hewan uji sebelum penyuntikan vaksin DPT-HB diperoleh berkisar antara 35.10C-37.10C. Setelah 2 jam penyuntikan vaksin DPT-HB, suhu tubuh tikus putih diukur kembali dan diperoleh hasil 36.930C-38.430C. Peningkatan suhu tubuh setelah 2 jam penyuntikan vaksin ini dibandingkan dengan hasil penukuran suhu tubuh sebelum disuntikkan vaksin merupakan tanda bahwa hewab uji telah mengssalami demam. Kelompok kontrol negatif yang diberikan sirup tanpa ekstrak secara oral, menunjukkan suhu tubuh hewan uji mengalami penurunan seperti suhu setelah penyuntikkan vaksin. Pada pemberian sirup ekstrak flavonoid daun alvokad dosis $1 / 4$ menunjukkan penurunan sebesar 0.40C. Untuk pemberian sirup ekstrak flavonoid daun alvokad dosis 1 , menunjukkan suhu tubuh hewan uji mengalami penurunan suhu sebesar $1.33^{\circ} \mathrm{C}$. Dan pemberian sirup ekstrak flavonoid daun alvokad dosis 2 , menunjukan suhu tubuh hewan uji mengalami penurunan suhu sebesar 0,6. Sedangkan pemberian sirup ekstrak flavonoid daun alvokad dosis 3, menunjukan suhu tubuh hewan uji mengalami kenaikkan suhu sebesar -0,2. Dari hasil yang didapatkan, dapat disimpulkan bahwa dosis sirup antipiretik ekstrak flavonoid daun alvokad yang paling efektif adalah dosis 1 .
\end{abstract}

Kata kunci : antipyretics, alvocado leaves, flavonoids

Abstract
This study aims to determine the most effective dose in reducing fever in white rats induced by DPT-HB
vaccine. The research method is an experimental laboratory using the method without heating for the
manufacture of syrup. The results of initial temperature measurements in all treatment groups of white rats
which is the normal temperature of the test animals before the DPT-HB vaccine is obtained ranged between
$35.10 \mathrm{C}-37.10 \mathrm{C}$. after 2 hours of DPT-HB vaccine injection, the body temperature of the white rats was
measured again and the results obtained were $36,930 \mathrm{C}-38,430 \mathrm{C}$. an increase in body temperature after 2 hours
of injecting this vaccine compared to the results of measuring body temperature before the vaccine is injected
is a sign that the test animal has experienced a fever. The negative control group which was given syrup without
extract orally, showed the body temperature of the test animals had decreased as the temperature after injecting
the vaccine. On the administration of alvocate leaf flavonoid syrup, the dose $1 / 4$ showed a decrease of $0.40 \mathrm{C}$.
For the administration of dosage flavonoid syrup extract dosage 1 , it showed that the body temperature of the

93 I Latjandu/JBE 4(3) (Desember 2019 ) 93-97 
test animals had a temperature drop of 1,330C. And administration of Alvocado leaf flavonoid syrup extract dose 2, showed that the body temperature of the test animals had a temperature drop of 0.6 . While the administration of Alvocado leaf flavonoid extract syrup dose 3, showed that the body temperature of the test animals experienced a temperature increase of -0.2 . From the results obtained, it can be concluded that the most effective dose of antipyretic syrup of alvocado leaf flavonoid extract is dose 1.

Keywords: Flavonoid, Antipyretic, Syrup

\section{PENDAHULUAN}

Sirup adalah sediaan pekat dalam air dari gula atau pengganti gula dengan atau penggganti gula dengan atau tanpa penambahan bahan pewarna dan zat obat (Ansel, 2014). Sediaan sirup memiliki beberapa kelebihan yaitu lebih cepat diabsorbsi tubuh dan mudah dikonsumsi baik untuk anak-anak maupun orang dewasa. Obat-obat yang dapat dibuat dalam sediaan sirup salah satunya adalah obat untuk antipiretik.

Antipiretik merupakan obat yang banyak digunakan untuk mengatasi demam. Namun obat antipiretik bersifat asam, sehingga lebih banyak terkumpul dalam sel yang bersifat asam seperti dilambung, ginjal, dan jaringan yang mengalami peradangan. Keadaan seperti inilah yang menyebabkan cenderungnya masyarakat mencari altematif lain dari pengobatan yaitu menggunakan obat tradisional.

Secara tradisional tanaman yang dimanfaatkan sebagai tanaman obat salah satunya adalah tanaman alvokad (Persea americana Mill). Menurut pengalaman empiris masyarakat sering menggunakan daun alvokad sebagai obat penurun demam, dan telah dibuktikan secara ilmiah melalui penelitian sebelumnya bahwa infus daun alvokad yang diberikan secara oral pada tikus putih (Rattus novergicus $\mathrm{L}$ ) memiliki efek antipiretik, karena adanya kandungan senyawa flavonoid (Dalihade, 2013).

Dalam hal ini pengembangan obat tradisional harus lebih ditingkatkan menjadi bentuk sediaan farmasi yang salah satunya adalah sediaan sirup. Penelitian ini bertujuan Untuk mengetahui dosis yang paling efektif dalam menurunkan demam pada tikus putih yang diinduksi vaksin DPT-HB.

\section{METODE}

\section{Tempat dan Waktu Penelitian}

Penelitian ini dilaksanakan di Laboratorium Farmasi Sekolah Tinggi Ilmu kesehatan Trinita Manado. Dan dimulai pada bulan Mei 2019 sampai November 2019.

\section{Bahan dan Cara Kerja}

Bahan-bahan yang digunakan yaitu Tikus putih jantan, Daun Alvokad, Vaksin DPTHB, Etanol, Aquades, Klorofom, Gula, Essence, Pasta, Asam Benzoat, Vaseline.

Prosedur penelitian dimulai dengan pengambilan dan penyiapan sampel yang setelah kering diekstraksi dengan klorofom sebanyak 3 liter. Sampel ini diekstraksi secara berulangulang hingga jernih. Kemudian debrisnya dikeringkan dengan cara diangin-anginkan. Setelah debris menjadi kering, diekstraksi kembali dengan etanol sebanyak 3 liter. Setelah itu ekstrak yang diperoleh diuapkan dengan menggunakan rotary evaporator sampai diperoleh ekstrak flavonoid pekat. 
Untuk perlakuan masing-masing tikus putih diukur suhunya melalui rektal dan dicatat untuk mengetahui suhu normalnya. Setelah itu setiap tikus putih disuntikkan dengan vaksin DPT-HB sebanyak $0.1 \mathrm{ml}$ untuk menaikkan suhu tubuhnya. Setelah 2 jam tikus putih diukur suhu tubuhnya untuk mengetahui perubahan suhu yang terjadi. Bila terjadi kenaikkan suhu setiap kelompok diberikan perlakuan yaitu:

Perlakuan I : tikus diberi sirup tanpa ekstrak

Perlakuan II : tikus diberi sirup dosis 1/4

Perlakuan III : tikus diberi sirup dosis 1

Perlakuan IV : tikus diberi sirup dosis 2 Perlakuan V: tikus diberi sirup dosis 3 Setelah diberikan perlakuan, tikus putih diukur suhunya pada setiap 30 menit selama 3 jam untuk melihat penurunan suhu pada tikus putih.

Untuk analisis data yang diperoleh, akan dianalisis secara deskriptif dan disajikan dalam bentuk grafik dan tabel.

\section{HASIL DAN PEMBAHASAN}

\section{Hasil}

Hasil disajikan secara logis, singkat, dan sistematis (tabel dan ilustrasi penting harus disertakan). Pembahasan merupakan tinjauan atas hasil penelitian; terkait di dalamnya, argumentasi logis serta perbandingan dengan hasil-hasil penelitian lain (rujukan literatur).

Hasil pengukuran efektivitas antipiretik sirup ekstrak flavonoid daun alvokad terhadap tikus putih yang diinduksi vaksin DPT-HB, dapat dilihat pada tabel 1 dibawah ini:

Tabel 1. Hasil rata-rata pengukuran suhu

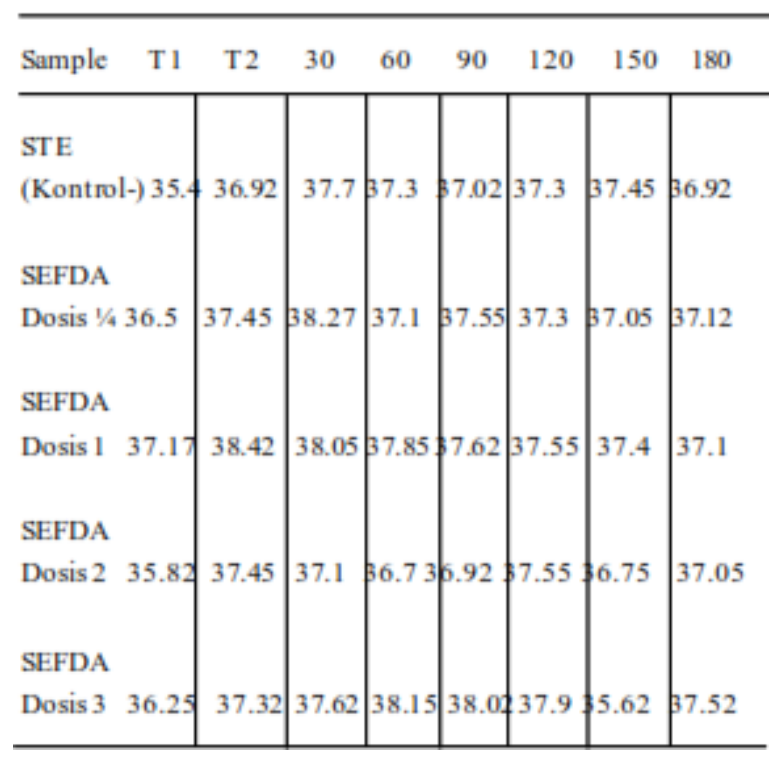

\section{Pembahasan}

Hasil penukuran suhu awal pada semua kelompok perlakuan tikus putih yang merupakan suhu normal dari hewan uji sebelum penyuntikan vaksin DPT-HB diperoleh 
berkisar antara 35.10C-37.10C. setelah 2 jam penyuntikan vaksin DPT-HB, suhu tubuh tikus putih diukur kembali dan diperoleh hasil 36.930C - 38.430C.

Peningkatan suhu tubuh setelah 2 jam penyuntikan vaksin ini dibandingkan dengan hasil penukuran suhu tubuh sebelum disuntikkan vaksin merupakan tanda bahwa hewan uji telah mengalami demam. Untuk penyuntikan vaksin DPT-HB dilakukan secara intramuscular pada bagian otot paha tikus putih dengan tujuan demam yang ditimbulkan dari penginjeksian DPT-HB mudah bereaksi (Tamsuri, 2006).

Pada kelompok control negatif yang diberikan sirup tanpa ekstrak secara oral, menunjukkan adanya kenaikkan suhu pada menit ke 30. Dan pada menit ke 60 dan 90 mengalami penurunan suhu tubuh tikus putih kemudian naik kembali pada menit ke 120 sampai pada menit 150. Dan terjadi penurunan suhu lagi pada menit 180 hinggga $36,93^{\circ} \mathrm{C}$. Dan jika dibandingkan dengan suhu 2 jam setelah penyuntikan vaksin DPT-HB, suhu tubuh hewan uji yang mengalami kenaikkan suhu kembali turun seperti suhu setelah penyuntikkan vaksin. Penurunan suhu yang terjadi ini disebabkan karena sirup tanpa ekstrak ini berbentuk sediaan cair yang banyak mengandung air. Dimana pemberian air ini dapat menyebabkan terjadinya evaporasi, yang merupakan suatu mekanisme pemindahan panas tubuh melaluli penguapan air dari kulit. (Guyton dan Hall, 1997).

Pada pemberian sirup ekstrak flavonoid daun alvokad dosis $1 / 4$ menunjukkan kenaikkan suhu pada menit ke 30, kemudian penurunan suhu terjadi pada suhu ke 60. Namun pada menit ke 90 terjadi kenaikkan suhu dan turun kembali pada menit ke 120 sampai menit ke 150 . Tapi pada menit ke 180 terjadi kenaikkan suhu kembali mencapai $37.12^{\circ} \mathrm{C}$. Dan jika dibandingkan dengan suhu 2 jam setelah penyuntikan vaksin DPT-HB, suhu tubuh hewan uji hanya mengalami penurunan sebesar $0.33^{\circ} \mathrm{C}$. Hal ini disebabkan karena dosis yang diberikan tidak mampu memberikan efek terapi yang maksimal sebagai antipiretik, sehingga menyebabkan naik turunnya suhu tubuh yang tidak stabil.

Untuk pemberian sirup ekstrak flavonoid daun alvokad dosis 1menunjukkan penurunan suhu secara bertahap sampai pada menit ke 180. Dimana suhu tubuh hewan uji mencapai suhu tubuh awal hewan uji yaitu $37.17^{\circ} \mathrm{C}$. Dan jika dibandingkan dengan suhu 2 jam setelah penyuntikan vaksin DPT-HB, suhu tubuh hewan uji mengalami penurunan suhu sebesar $1.32^{\circ} \mathrm{C}$. Hal ini disebabkan dosis pemberian sirup ekstrak flavonoid daun alvokad yang diberikan pada hewan uji memberikan efek terapi yang dibuktikan dengan adanya penurunan suhu.

Pada pemberian sirup ekstrak flavonoid daun alvokad dosis 2, menunjukan penurunan suhu pada menit ke 30 sampai ke 60 Kemudian pada menit ke 90 sampai menit ke 120 terjadi kenaikan suhu tubuh dan turun kembali hingga 37,05. Dan jika dibandingkan dengan suhu 2 jam setelah penyuntikan vaksin DPT-HB, suhu tubuh hewan uji mengalami penurunan suhu sebesar 0,4 .

Sedangkan pada pemberian sirup ekstrak flavonoid daun alvokad dosis 3, menunjukan kenaikan suhu pada menit ke 30 sampai menit ke 60. Dan turun pada menit ke 90 sampai menit ke 150, namun naik kembali pada menit ke 180 mencapai 37,52. 


\section{KESIMPULAN}

Dari hasil penelitian dapat disimpulkan bahwa dosis yang paling efektif adalah dosis 1 Hal ini dikarenakan dosis 1 menunjukkan penu-runan suhu secara bertahap dan signifikan dimana suhu tubuh hewan uji mencapai suhu tubuh awal sebelum perlakuan yaitu $37.1^{\circ} \mathrm{C}$.

\section{DAFTAR RUJUKAN}

Ansel, H. C. 2014. Pharmaceutical Dosae Forms and Drugg Delivery Systems. Edisi X.Wolters Kluwer, Health.

Baratawidjaja G. K. dan Renanis I. 2010. Imunologi Dasar. Jakarta: Balai Penerbit FKUI.

Dalihade. 2013.Uji Efektivitas Antipiretik Infus Daun Alvokad (Persea Americana Mill) Terhadap Tikus Putih (Rattus Norveicus L) yang Diinduksi Vaksin DPT-HB. Skripsi Fakultas MIPA, Jurusan Farmasi Universitas Kristen Indonesia Tomohon.

Dalimartha S. 2008. Atlas Tumbuhan Obat Indonesia, Jilid V. Jakarta: Pustaka Bunda.

El-Radhi, Sahid et all. 2009. Clinical Manual of Fever. Berin: Springer.

Hartati S. 2008. Uji efek Antipiretik Infusa Herba Teki (Kyllina brevifolia (Rottb) Hask) pada Kelinci Putih Jantan alur New Zealand. Skripsi Fakultas Farmasi Universitas Muhammadiyah, Surakarta.

Hayati, Jannah dan Ningsih,.2012. Ilmu Obat Alam, Penerbit Swadaya, Yogyakarta.

Irawati N.A.V. 2015. Antihypertensive Effects of Avocado Leaf Extract (Persea Americana Mill). Jurnal Majority, Vol.4 No.1

Kaneshiro N.K. dan Zieve D. 2010. Fever. University of Washinton. Diakses tanggal 7 Agustus 2018.

Orun E, Polat A, Andan H, et al. 2013. Incorrect Prescription of Intravenous Paracetamol in a Pediatric Patient. Hippokratia.

Orwa et al. 2009. Persea Americana. Agroforestry Database. Diakses 7 Agustus 2018.

Prasetyowati, Retno P, Fera T. O. 2010. Pengambilan Minyak Biji Alpukat dengan Metode Ekstraksi. Jurnal kimia, No. 2. Vol. 17.

Ratna J. 2013. Faktor-faktor yang Berhubungan dengan Sikap Ibu Mengenai Ikutan Pasca Imunisasi (KIPI). SIMTAKP.

Rifatul, 2009. Efek Samping Obat Herbal terhadap Kesehatan Masyarakat. Diakses pada tanggal 18 Agustus 2018.

Suwertayasa, IMP. Bodhy, W. Edhy H.J2013. Uji Efek Antipiretik Ekstrak Etanol Daun Tembelekan (Lantana Camara L) pada Tikus Putih Jantan Galur Wistar. Pharmacon, 2 (3).

Widyasari R. Ratiningsih. R. 2017. Uji Aktivitas Antipiretik Ekstrak Etanol Kulit Jeruk Manis (Citrus X Aurantium L) terhadap Tikus Putih (Rattus Novergicus L) Jantan Galur Wistar yang Diinduksi Pepton 5\%. Jurnal Ilmiah Ibnu Sina 2 (2). 